\title{
Pharmacogenetic Study
}

National Cancer Institute

\section{Source}

National Cancer Institute. Pharmacogenetic Study. NCI Thesaurus. Code C129001.

A study that assesses variation in DNA sequence, usually within a single gene, and its effect on drug response. 